\section{Bazhenov V., Vahischevich $M$.}

\title{
RESEARCH OF NONLINEAR DYNAMIC DEFORMATION OF SPATIAL BODIES WITH CRACKS
}

Об’єктом досліджень є процес динамічної взаємодії складної системи циклічно-симетричних деталей опорного з'єднання з урахуванням наявності стаціонарних трішин. Для значної кількості конструктивних елементів та деталей, що експлуатуються в умовах динамічних навантажень, характерним є виникнення та розповсюдження тріщин в зонах суттєвих пластичних деформацій. Зокрема, для опорного пристрою, який являє собою циклічно симетричне тіло з граничним випадком неоднорідності, при дї імпульсних навантажень на гранииях з'єднань циліндричної частини з виступами виникають зони пластичної течії. За умови наявності в означених областях тріщин, виникає необхідність достовірного визначення параметрів руйнування та прогнозування росту тріщини в часі.

Для побудови моделей означеного класу об'єктів одним з найбільш універсальних та достовірних чисельних методів є напіваналітичний метод скінченних елементів.

В даній роботі представлені результати обчислення на базі напіваналітичного методу скінченних елементів параметрів механіки руйнування для об'єкта з неоднорідними фізико-механічними властивостями при наявності стаціонарних тріщин в умовах імпульсного навантаження та пластичних деформацій. Чисельне дослідження виконано в два етапи. На першому етапі встановлено закономірності пружно-пластичного динамічного деформування системи. Визначені найбільш ймовірні зони накопичення пошкоджень та виникнення тріщин, що є причиною виходу з ладу елементів конструкції. На другому етапі розглянута модель із тріщиною, яка розташована в зоні пластичних деформачій, обчислені значення динамічних коефічієнтів інтенсивності напружень та досліджено їх еволючію у часі.

Отримані результати досліджень можуть бути використані при чисельних розрахунках неоднорідних тіл з пошкодженнями типу тріщин в умовах пружно-пластичних динамічних деформацій.

Ключові слова: Әинамічне навантаження, скінченно-елементна модель, стаціонарні тріщини, параметри механіки руйнування.

Received date: 28.01 .2020

Accepted date: 28.02 .2020

Published date: 30.04 .2020
Copyright (C) 2020, Bazhenov V., Vabischevich M. This is an open access article under the CC BY license (http://creativecommons.org/licenses/by/4.0)

\section{Introduction}

The desire to increase the life of critical objects of modern technology leads to the use of structural elements and parts in the presence of cracks. In many cases, they are under the influence of non-stationary dynamic loads of various durations arbitrarily distributed in space and time. Determination of crack resistance of these objects is a decisive factor in preventing possible emergency situations.

Despite the technical difficulties and the high cost of conducting full-scale tests, solving the problems of calculating the dynamic parameters of the destruction of a specified class of objects using experimental methods is almost impossible. In this connection, the need arises for a more in-depth theoretical study of the behavior of such structures and the creation of numerous corresponding means for determining the dynamic parameters of fracture mechanics.

Analysis of known publications [1-3] shows that twodimensional bodies remain the main objects of study of fracture mechanics under dynamic loading. When considering spatial bodies for a given class of problems, as a rule, they are limited to objects with homogeneous physical and mechanical properties and stationary cracks.
The most common and universal numerical method for constructing models of this class of objects is the semianalytical finite element method (SAFEM), the development of which is reflected in [4-6]. Based on the SAFEM, approaches to determining the stress intensity factor (SIF) and the J-integral in spatial problems of statics and dynamics for homogeneous bodies with stationary cracks are widely considered [7-9]. At the same time, the problem of calculating the parameters of fracture mechanics on the SAFEM basis for bodies with inhomogeneous physicomechanical properties in the presence of cracks under conditions of pulsed loading is insufficiently covered in the literature. This confirms the relevance of theoretical research.

So, the object of research is the process of dynamic interaction of a complex system of cyclically symmetric parts of the support joint, taking into account the presence of stationary cracks. The aim of research is determination of the crack resistance parameters for parts of the above locking connection.

\section{Methods of research}

Numerous studies were carried out on the SAFEM basis using SAFEM software by the Research Institute 
of Structural Mechanics of the Kyiv National University of Construction and Architecture (KNUCA RI SM). The main task is to build a spatial end element model (SEM) of the object using the developed special finite elements that simulate the presence of a crack and contact.

The main (inner) part of the support joint (Fig. 1) is a massive cylinder with 4 rows of sector projections uniformly spaced along the annular coordinate on the outer surface. The outer part is also made in the form of a cylinder with 3 rows of projections on the inner surface.
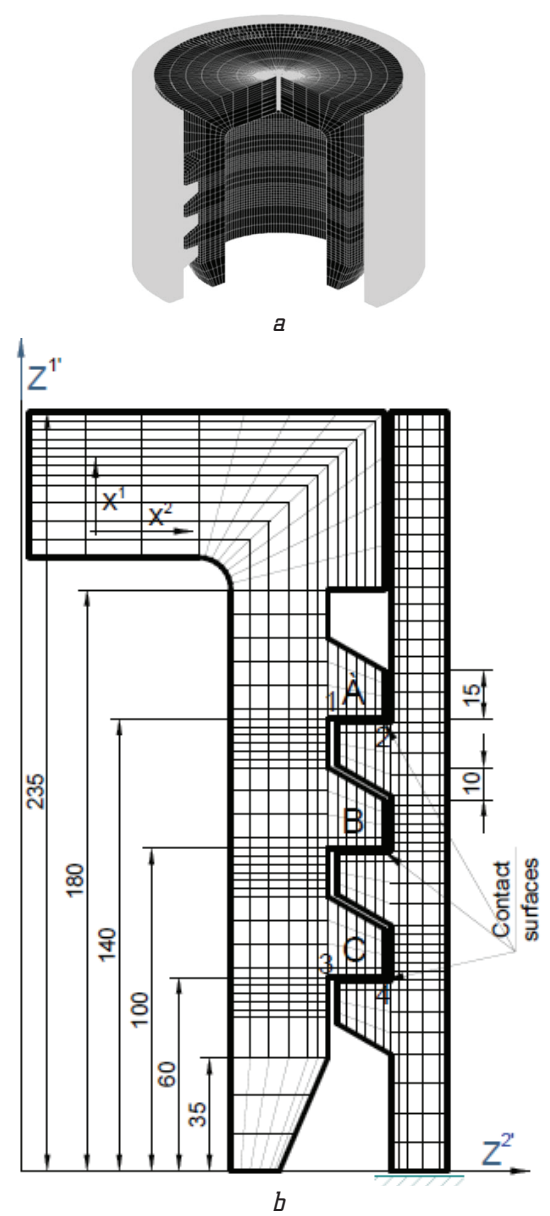

Fig. 1. Object of research: $a$ - computer model; $b$ - finite element model
The analysis of individual elements [10] shows a significant non-uniformity of the congestion of the projections along the annular coordinate; it requires spatial modeling of the joint as a cyclically symmetric structure. In a cross section, the structure is approximated by a set of homogeneous and inhomogeneous annular finite elements (FEs). In the region of cutouts, the elastic modulus, density, and Poisson's ratio are taken equal to zero. Modeling of contact interaction between performances is carried out using special contact FEs, which accept only compressive loads normal to the contact surface. Taking into account the presence of cracks in the zones of plastic deformations is ensured by introducing into the design scheme specially developed dynamics problems for FEs with cracks.

A study of the convergence of solutions shows that when the number of nodes in the grid region is more than doubled (from 500 to 940 ) or the number of members of the Fourier series from 12 to 20, the difference in maximum stresses does not exceed $5 \%$. When approximating the structure along the circumferential coordinate, 20 members of the Fourier series are contained, the grid is preserved in the cross section $-20 \times 47$, time step $\Delta t=3 \cdot 10^{-6} \mathrm{~s}$. To ensure the required accuracy of solving the system of equations, it is enough to use the value $\varepsilon=10^{-3}$.

\section{Research results and discussion}

The analysis of the stress-strain state of the object shows that the corner zones where structural performances are structurally combined with the cylinder body are maximally loaded. The value of the stress intensity obtained in these areas on the basis of elastic calculation reaches values exceeding the value of the yield strength of the material, leading to the need to solve the elastic-plastic problem of dynamic deformation.

At the initial stages of deformation, stress waves arise along the inner part $Z^{1^{\prime}}$ in the barrel, the level of which is significantly less than the yield strength. Plastic deformations occur during the oscillation of the entire part and are local in nature (areas of projections). First appear at $t=6.6 \cdot 10^{-5} \mathrm{~s}$ and develop to $t=29.1 \cdot 10^{-5} \mathrm{~s}$ when they acquire their maximum values. Zones of nonlinear work of the material are presented at performances in the form of isolines at time $t=29.1 \cdot 10^{-5} \mathrm{~s}$ (Fig. 2).
Through performances, an interaction (contact) occurs between the internal and external parts of the supporting device. The purpose of the object of research is the content of the projectile in the gun barrel. The phenomenon of the shot is modeled by a pulsed load applied to the upper end of the lid of the inner part. The rate of increase and the duration of the pressure allows to apply it instantly with intensity $q_{a}=0.739 \cdot 10^{8} \mathrm{~Pa}$ and hold it for a time interval $t \in\left[0 ; 2.4 \cdot 10^{-4}\right] \mathrm{s}$. The elastic modulus of the material $E=2.1 \cdot 10^{11} \mathrm{~Pa}, \rho=7.8 \cdot 10^{3}$ density $\mathrm{kg} / \mathrm{m}^{3}$, Poisson's ratio $\mathrm{v}=0.3$, yield strength $\tau_{s}=2.7 \cdot 10^{8} \mathrm{~Pa}$.

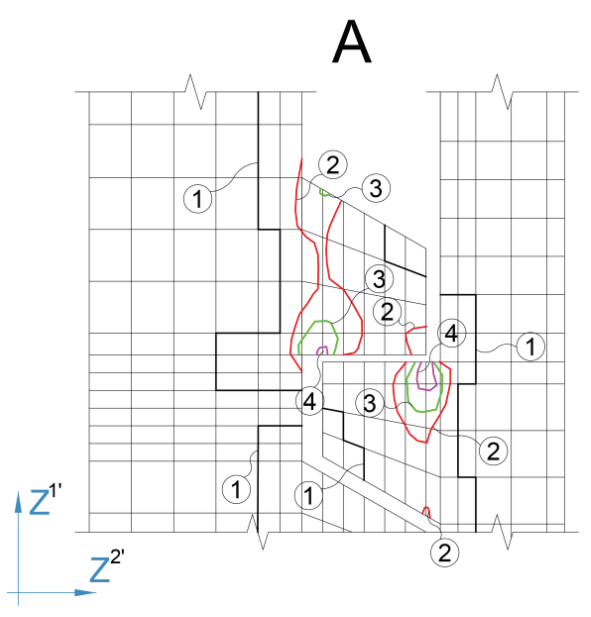

a

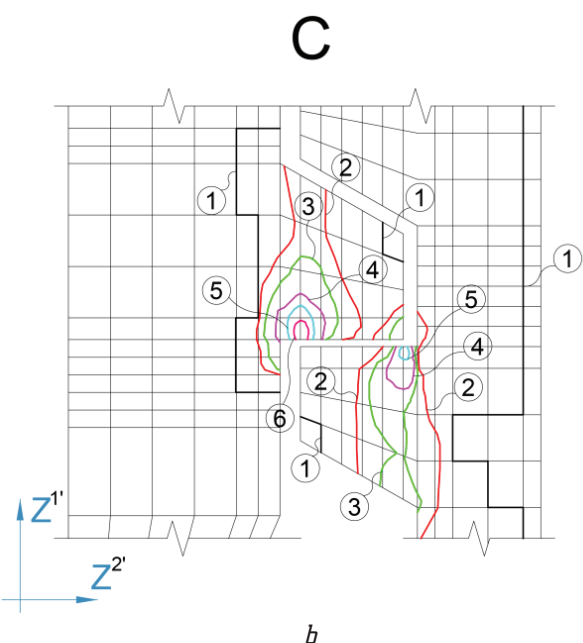

b

Fig. 2. The intensity of plastic deformations in section I-I: $a-$ in the zone of the third projection; $b-$ in the zane of the first projection $(1-0.0 \%, 2-0.09 \%, 3-0.19 \%, 4-0.28 \%, 5-0.37 \%, 6-0.47 \%)$ 
After determining the stress-strain state of the object in the areas of maximum plastic deformations using special finite elements, inclined annular cracks with vertices at the edges of the projections are modeled (Fig. 3).

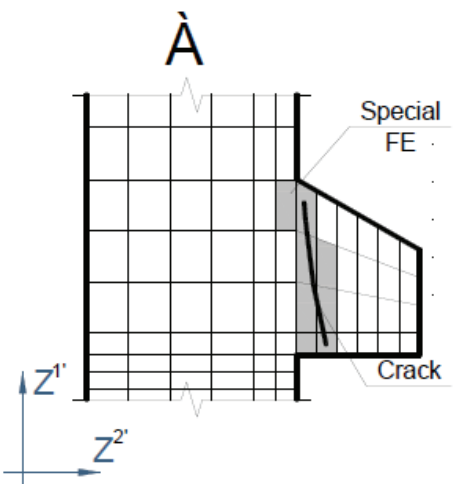

Fig. 3. Fragment of a finite element model with special finite elements with cracks

SIF calculation is carried out by two methods: direct (line) and based on the energy approach (reaction method, brand). The results are shown in Fig. 4 in the form of normalized values of dynamic SIF $K_{\varsigma} / q$. The stress intensity factor of the second kind $K_{I I}$ (dashed line, squares) is approximately $10 \div 12 \%$ of $K_{I}$ (solid lines, circles).

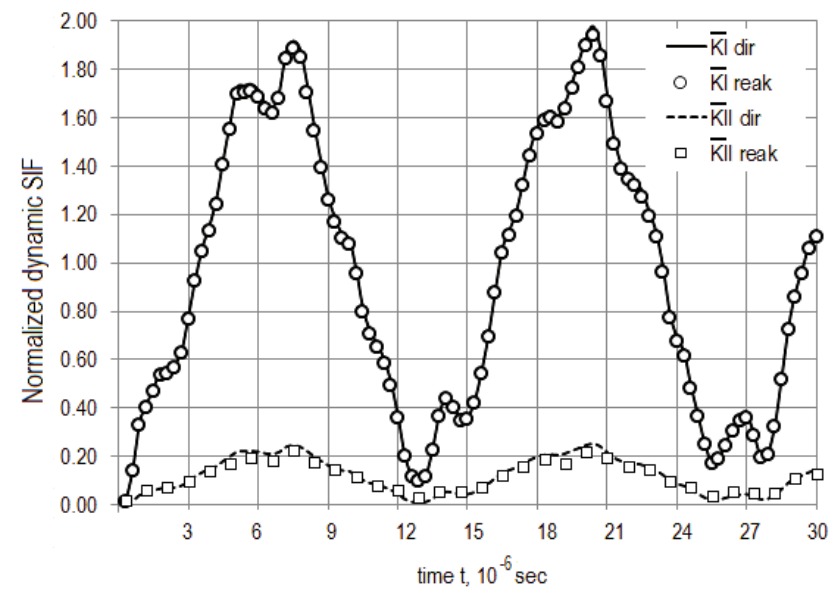

Fig. 4. The evolution of the dynamic stress intensity factor

As can be seen from the graphs in Fig. 4, the difference between the results obtained using various approaches does not exceed $2-3 \%$, which is quite acceptable for dynamic problems.

\section{Conclusions}

According to the results of the finite-element calculation of the details of the support connection, it is found that the corner zones are the most loaded, where sector performances are structurally combined with the cylinder body. The most probable zones of crack initiation that can occur in areas where the intensity of plastic deformations are from 0.19 to $0.47 \%$ are determined. The calculated values of the dynamic stress intensity factors (DSIF) and studies of their evolution in time showed that the maximum values of the normalized DSIF of the first kind do not exceed 2.0, and the second kind -0.25 . Moreover, the values change cyclically with a period of $12.9 \cdot 10^{-5} \mathrm{~s}$. The obtained research results can be used in numerous calculations of inhomogeneous bodies with damage such as cracks in the conditions of elastic-plastic dynamic deformations.

\section{References}

1. Funari, M. F., Lonetti, P., Spadea, S. (2019). A crack growth strategy based on moving mesh method and fracture mechanics. Theoretical and Applied Fracture Mechanics, 102, 103-115. doi: http://doi.org/10.1016/j.tafmec.2019.03.007

2. Ooi, E. T., Shi, M., Song, C., Tin-Loi, F., Yang, Z. J. (2013) Dynamic crack propagation simulation with scaled boundary polygon elements and automatic remeshing technique. Engineering Fracture Mechanics, 106, 1-21. doi: http://doi.org/10.1016/ j.engfracmech.2013.02.002

3. Zhang, Y., Zhuang, X. (2019). Cracking elements method for dynamic brittle fracture. Theoretical and Applied Fracture Mechanics, 102, 1-9. doi: http://doi.org/10.1016/j.tafmec.2018.09.015

4. Bazhenov, V. A., Guliar, O. I., Piskunov, S. O., Sakharov, O. S. (2002). CHiselne modeliuvannia neliniinogo deformuvannia, kontinualnogo i diskretnogo ruinuvannia metodom skinchennikh elementiv. Tekhnologicheskie sistemy, 2, 30-33.

5. Guliar, A. I. (1984) Ob odnom metode rascheta prostranstvennykh konstruktsii na osnove obobshcheniia poluanaliticheskogo varianta MKE dlia zamknutykh nekrugovykh konechnykh elementov. Soprotivlenie materialov i teoriia sooruzhenii, 44, 44-46.

6. Hrechukh, N. A., Pyskunov, S. O., Ostapenko, R. M. (2006) Obchyslennia KIN v prostorovykh tilakh obertannia pry temperaturnomu navantazhenni. Opir materialiv $i$ teoriia sporud, 80, 38-53.

7. Guliar, A. I., Topor, A. G., Solodei, I. I. (1997). Obobshchenie PMKE dlia issledovaniia dinamicheskogo deformirovaniia neodnorodnykh tel vrashcheniia pri impulsnom nagruzhenii. Soprotivlenie materialov $i$ teoriia sooruzhenii, 63, 103-114.

8. Solodei, I. I. (2002) Napivanalitychnyi metod skinchennykh elementiv v doslidzhenni pruzhnoplastychnykh kolyvan neodnoridnykh pryzmatychnykh til. Opir materialiv $i$ teoriia sporud, 71, 90-98.

9. Solodei, I. I., Vabishchevych, M. O., Sakharov, O. S., Huliar, O. I. (2006). Vyznachennia koefitsiientiv intensyvnosti napruzhen pryzmatychnykh til z trishchynamy pry dii dynamichnoho navantazhennia. Opir materialiv $i$ teoriia sporud, 78, 61-76.

10. Sakharov, A. S., Guliar, A. I., Topor, A. G. (1986). Analiz napriazhenno-deformirovannogo sostoianiia tel vrashcheniia s vyrezami, narushaiushchimi osevuiu simmetriiu. Problemy prochnosti, 6, 69-73.

Bazhenov Viktor, Doctor of Technical Sciences, Professor, Head of Department of Structural Mechanics, Kyiv National University of Construction and Architecture, Ukraine, e-mail: vikabazh@ukr.net, ORCID: http://orcid.org/0000-0002-5802-9848

Vabischevich Maksim, PhD, Department of Structural Mechanics, Kyiv National University of Construction and Architecture, Ukraine, e-mail: vabix@ukr.net, ORCID: http://orcid.org/00000002-0755-5186 